\title{
Further notes on Napoca Simon, 1901, the genus of beetle-like jumping spiders (Aranei: Salticidae), with a description of a new species
}

\author{
Аальнейшие заметки о Napoca Simon, 1901 (Aranei: Salticidae), \\ роде жукоподобных пауков-скакунчиков, \\ с описанием нового вида
}

\author{
Dmitri V. Logunovi ${ }^{1}$ Michael Schäfer ${ }^{2}$ \\ А.B. $\Lambda$ огунов ${ }^{1}$, М. Шефер ${ }^{2}$ \\ 1 The Manchester Museum, The University of Manchester, Oxford Road, Manchester M13 9PL, UK. E-mail: \\ dmitri.v.logunov@manchester.ac.uk. The corresponding author. \\ ${ }^{2}$ An den Bänken 36b, D-12589 Berlin, Germany. E-mail: michael.schaefer@kleinesganzgross.de
} nean.

KEY WORDS: beetle mimicry, definition, diagnosis, Harmochireae, taxonomic comments, the Mediterra-

КЛЮЧЕВЫЕ СЛОВА: мимикрия под жуков, определение, диагноз, Harmochireae, таксономические заметки, Средиземноморье.

ABSTRACT. The poorly known genus Napoca Simon, 1901 is redefined and diagnosed. A new species, Napoca constanzeae sp.n. ( $\left.\sigma^{7}\right)$ from Andalusia (Spain), is diagnosed and described. The unknown female of Napoca insignis (O. Pickard-Cambridge, 1872) is described for the first time. A distributional map for both species is provided.

РЕЗЮМЕ. Малоизвестный род Napoca Simon, 1901 переописан и диагностирован. Описан новый вид Napoca constanzeae sp.n. ( $\left.\bigcirc^{7}\right)$ из Андалузии (Испания). Впевые описана неизвестная самка Napoca insignis (O. Pickard-Cambridge, 1872). Приведена карта распространения обоих видов.

\section{Introduction}

The genus Napoca Simon, 1901 was erected by Simon [1901] for Salticus insignis O. Pickard-Cambridge, 1872 from the Near East, which is still known from the single male. The holotype male was redescribed by Logunov [2001], who also removed Napoca from the synonymy with Bianor Peckham et Peckham, 1886 [contra Prószyñski, 1990: 72] and provided its improved diagnosis. Nevertheless, till now the taxonomic status of Napoca has remained obscure, as it is the monotypic genus known from the holotype male only. Recent findings of the female of $N$. insignis and a second, new species from Spain have allowed us to reexamine the genus Napoca and to provide a better justified definition thereof. Thus, the main aims of the present paper are (1) to redefine and diagnose the genus Napoca, and (2) to (re)describe both of its species on the basis of newly collected materials.

\section{Material and methods}

The studied specimens have been deposited in or borrowed from the following museums: OUMNH Oxford University Museum of Natural History, UK (curator: Zoe Simmons); TAU — the Department of Zoology of the Tel-Aviv University, Israel (curator: Sergei L. Zonstein), and ZMB — Museum für Naturkunde, Leibniz Institute for Evolution and Biodiversity Science, Invalidenstrasse 43, D-10115 Berlin, Germany (curator: Jason A. Dunlop).

The format of species description and terminology follow Logunov [2001]. For the leg spination the system adopted is that used by Ono [1988]. Abbreviation used in the text: D - described. Copulatory organs: RTA - retrolateral tibial apophysis, TK - tegular knob. Eyes: AME - anterior median eye, ALE anterior lateral eye, PME - posterior median eye, PLE - posterior lateral eye. Leg segments: Fm femur, $\mathrm{Pt}$ - patella, $\mathrm{Tb}$ - tibia, $\mathrm{Mt}$ - metatarsus, $\mathrm{Tr}$ tarsus. Position of leg spines: $\mathrm{d}$ - dorsal, $\mathrm{pr}$ - prolateral, rt - retrolateral, v - ventral. In the following descriptions, the term 'cheeks' is used to describe the areas of carapace situated below the ALE-PLE line, on both sides of the clypeus. The sequence of leg segments in measurement data is as follows: femur + patella + tibia + metatarsus + tarsus (total). All measurements are in $\mathrm{mm}$.

\section{Genus Napoca Simon, 1901}

Napoca Simon, 1901: 642, fig. 747G. Type species: Salticus insignis O. Pickard-Cambridge, 1872; subsequent designation by Simon [1901]. 


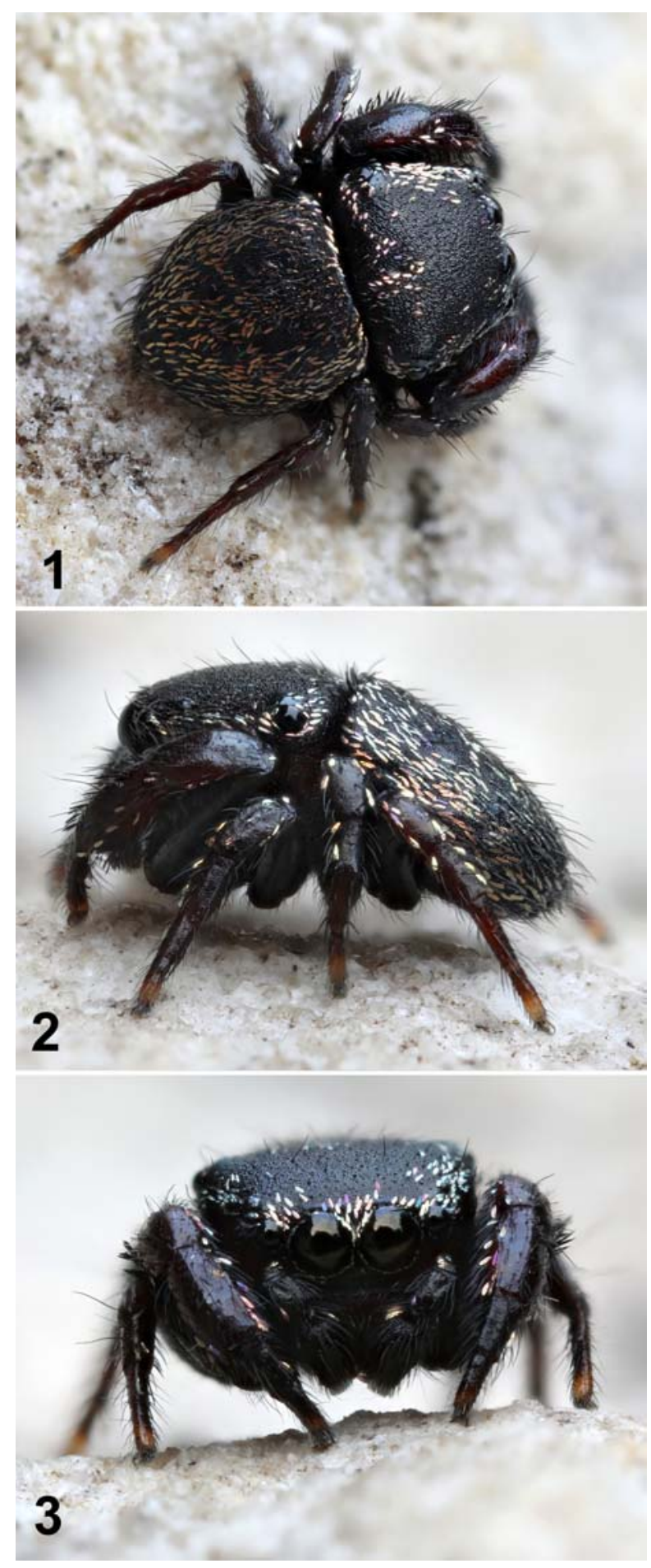

Figs 1-3. General appearance of the holotype male of Napoca constanzeae sp.n.

Рис. 1-3. Общий вид голотипа-самца Napoca constanzeae sp.n.

DEFINITION. Small unidentate, beetle-like jumping spiders (Figs 1-3, 24-27), ranging in body length from 3.05 to $4.35 \mathrm{~mm}$ in the males and about $5 \mathrm{~mm}$ in the females. Sexes similar in general body shape and sexual dimorphism is poorly marked. The males of
Napoca differ from the females in having the slightly smaller male body size (by 10-15\%), the well-marked ectal tooth on endites (cf. Figs 16, 20 and 37) and the proportionally larger dorsal scutum covering the entire abdomen (Figs 4, 9); the female scutum is smaller and covers the proximal half of dorsum only (Fig. 24). CARAPACE: as wide as long, or slightly wider than long (length/width ratio 0.95-1.16), and rather high, with the posterior half of the thorax declining abruptly, almost vertically (Figs 7, 12, 27); carapace is sparsely covered with elongated recumbent white scales (Figs $1-3,24)$; fovea is poorly marked, looking like a small oval depression situated in between PLEs. EYEs: in three rows, with small black areas surrounding eyes; PMEs are markedly closer to the first eye row than to PLEs (arrowed in Figs 19, 34); clypeus vertical, their height $44-50 \%$ of AME-diameter. CHELICERAE: small, vertical and of usual shape, with no projections or other modifications (Figs 6, 11, 26); promargin with two small teeth, retromargin with a medium-sized tooth (Figs 21, 36). Endites: Subparallel, of usual shape, with obtuse, white tips; in the males, each endite possesses a keel-shaped rim ended up with an ectal tooth (Figs 16, 20), in the females, only a poorly marked keel is visible (Fig. 37). LABIUM: triangular, with the obtuse tip directing forward (Figs 16, 37). STERnum: ovoid, longer than wide, slightly narrower at its rear end (Fig. 35). Pedicel: short, not visible in dorsal view. ABDOMEN: oval to bean-shaped, could be flat in the males (e.g., in N. constanzeae sp.n.; Figs 2, 12), always overhangs the carapace, entirely covering its thorax; colour pattern is absent or poorly-marked, e.g. as in the male of $N$. insignis (O. Pickard-Cambridge, 1872), consisting of two pairs of large round yellowish spots (Fig. 4). BOOK-LUNG COVERS: not sclerotized. SPINNERETS: small and very compact. LEG FORMULA: I,IV,III,II in both sexes. LEGS: the first pair is always stronger and longer, with swollen and contrasting-coloured femora, $\mathrm{Tb}$ I ventrally with a row of dense feathery bristles in both sexes (Figs 8,13), the dorsal row of feathery bristles absent. Leg SPINATION. All leg segments with spines, except for spineless Pt and sometimes Mt IV; the constant pattern is as follows: Fm I-IV 1/2ap; Tb III pr 01; Mt I and II v 2-2ap; spine pattern on other segments varies. Female palp: general form; without an apical claw. Male palp (Figs 14, 15, 17, 18): Fm of usual shape; cymbium of usual shape, with no apical spine and without processes or projections; RTA straight, markedly wide at its base; TK is well-marked, its tip is situated at about the level of RTA tip or a bit lower (as seen in retrolateral view); embolus thin and relatively short. FEMALE COPULATORY ORGANS (Figs 29-33): epigyne with the well-developed central blind-ending pocket; spermathecae is of two-chambered configuration as in all other Harmochireae genera (see Logunov [2001]), but primary and secondary receptacles seem to be fused together; insemination ducts rather long, forming the clear first loop; fertilization ducts well-developed and visible. 


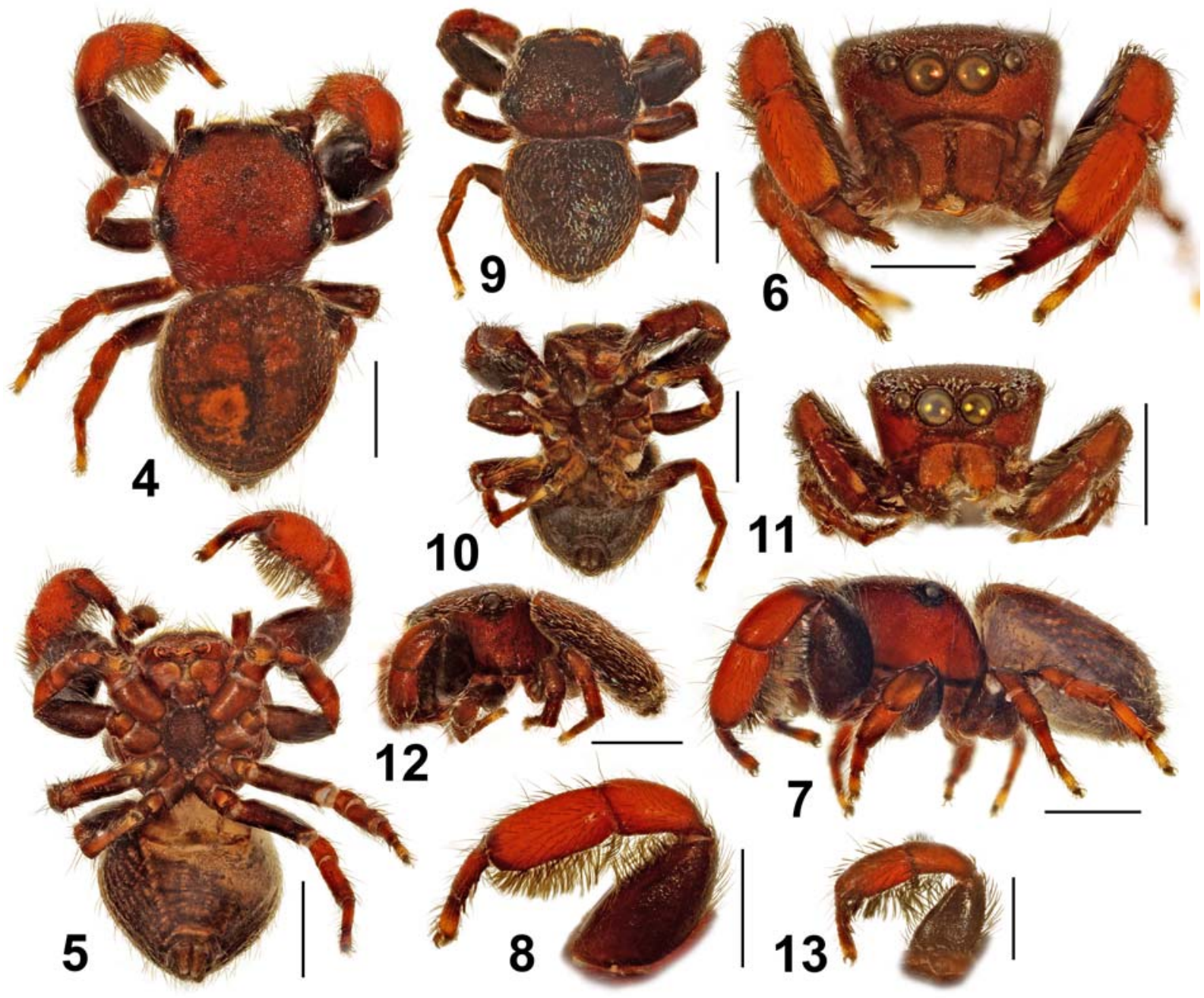

Figs 4-13. General appearance and the first legs of the males of Napoca insignis (O. Pickard-Cambridge, 1872) (4-8), and $N$. constanzeae sp.n., the holotype (9-13): 4, 9- dorsal view; 5, 10 - ventral view; 6,11 - frontal view; 7, 12 - lateral view; 8, 13 - left first legs, retrolateral view. Scale bars $=1 \mathrm{~mm}$.

Рис. 4-13. Общий вид и передняя нога самцов Napoca insignis (O. Pickard-Cambridge, 1872) (4-8), и N. constanzeae sp.n., голотип (9-13): 4, 9 - вид сверху; 5, 10 - вид снизу; 6, 11 - вид спереди; 7, 12 - вид сбоку; 8, 13 - первая нога, вид сзадисбоку. Масштаб 1 мм.

DIAGNOSIS AND AFFINITIES. From all other Harmochireae genera [sensu Logunov, 2009], Napoca can be easily distinguished by the following two characters: PMEs are situated near ALEs (arrowed in Figs 19, 34; midway between ALEs and PLEs in other Harmochireae genera) and abdomen markedly overhangs the carapace, entirely covering its thorax (Figs 2, 7, 12). A useful additional diagnostic character is $\mathrm{Tb} \mathrm{I}$ bearing a well-developed ventral fringe of feathery bristles in both sexes (Figs 8, 13, 28); this character clearly separates Napoca from Harmochirus Simon, 1885 and Sibianor Logunov, 2001 which possess both dorsal and ventral fringes and from Bianor and Modunda Simon, 1901 having none. However, most species of Microbianor Logunov, 2000 and Neaetha Simon, 1884 also have the ventral fringe on $\mathrm{Tb} \mathrm{I}$, but both differ from Napoca in having PMEs situated midway between ALEs and PLEs and, more importantly, the distinct copulatory organs, especially in the females [cf. Logunov, 1996, 2000, 2009]; besides, their abdomen never overhangs the carapace.

According to Maddison [2015], Napoca belongs to the subtribe Harmochirina of the tribe Plexippini. However, within the Harmochirina, Napoca and six other genera form a compact group known as the Harmochireae [sensu Logunov, 2009] or the harmochirines s.str. [sensu Maddison, 2015]. This group includes jumping spiders that are strongly united by molecular data (at least, the genera Bianor and Sibianor that have been sequenced to date; see Maddison et al. [2008]) and often have beetle-like appearance. Of them, Napoca seems to be the strongest beetle-mimic (Figs 1-3). 


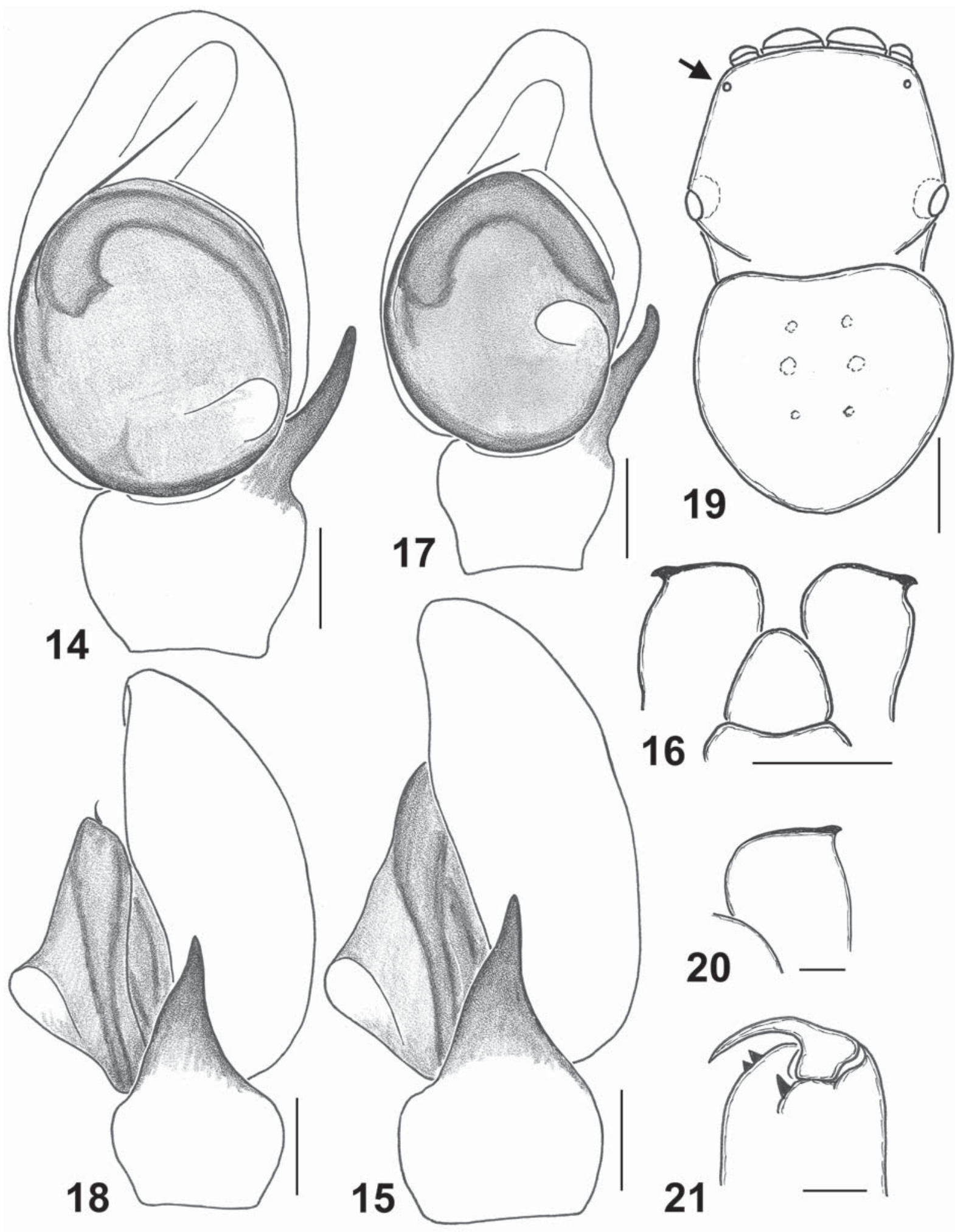

Figs 14-21. Copulatory organs and somatic characters of the males of Napoca insignis (O. Pickard-Cambridge, 1872) (14-16), and N. constanzeae sp.n., the holotype (17-21): 14, 17 - palp, ventral view; 15, 18 - ditto, retrolateral view; 19 - body, dorsal view; 16, 20 endites and labium, ventral view, 21 - left chelicera, ventral view. Scale bars $=(14,15,17,18,20,21) 0.1 \mathrm{~mm},(16,19) 0.5 \mathrm{~mm}$.

Рис. 14-21. Копулятивные органы и соматические признаки самцов Napoca insignis (O. Pickard-Cambridge, 1872) (14-16), и N. constanzeae sp.n., голотип (17-21): 14, 17 - пальпа, вид снизу; 15, 18 - тоже, вид сзади-сбоку; 19 - тело, вид сверху; 16, 20 эндиты и нижняя губа, вид снизу, 21 - левая хелицера, вид снизу. Масштаб $(14,15,17,18,20,21)$ 0,1 мм, $(16,19) 0,5$ мм. 


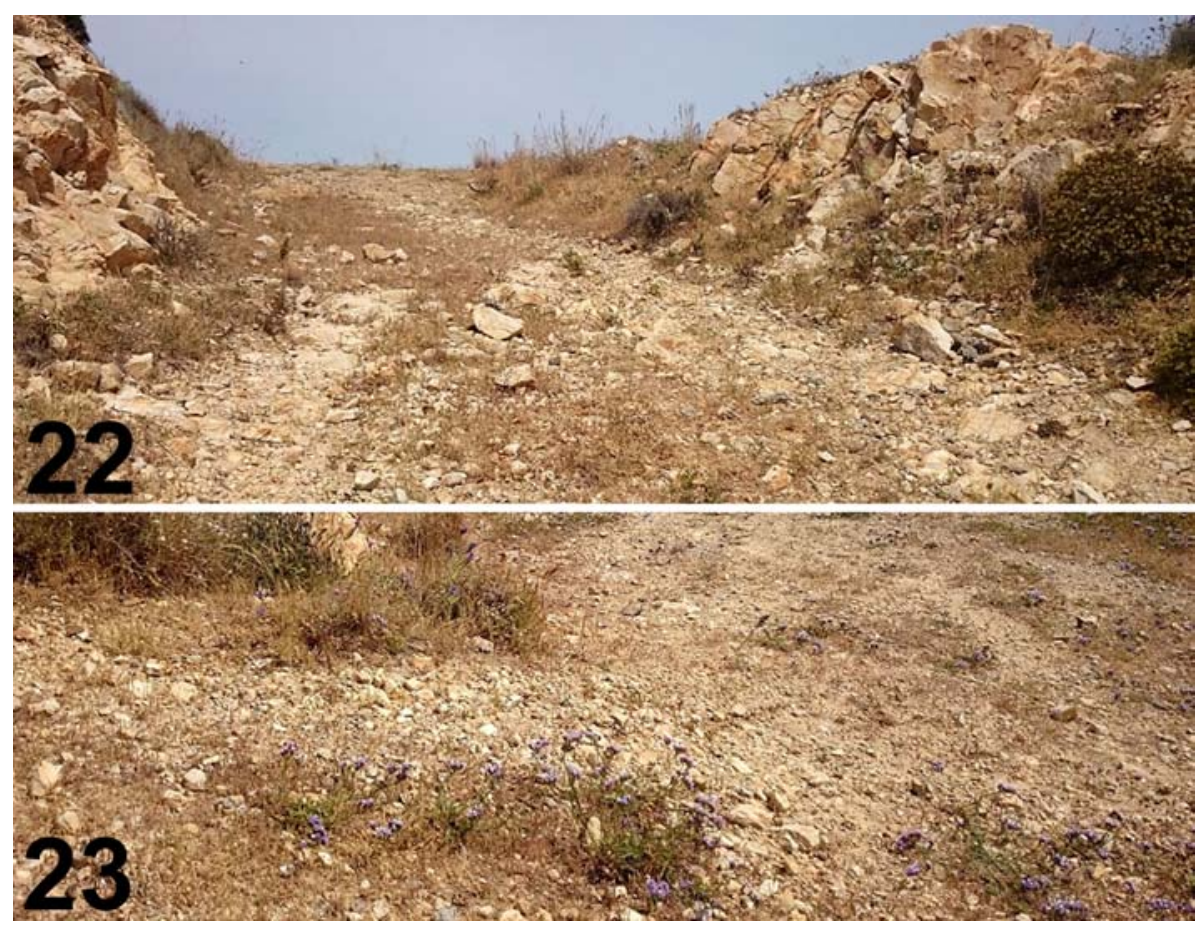

Figs 22-23. Habitat of Napoca constanzeae sp.n., the type locality.

Рис. 22-23. Местообитание Napoca constanzeae sp.n., типовой локалитет.

DISTRIBUTION. The Mediterranean, with one species recorded from Spain (Andalusia) and another from Israel (Map).

COMPOSITION. To date, two species have been described: Napoca constanzeae sp.n. and N. insignis (O. Pickard-Cambridge, 1872).

\section{Survey of species}

\section{Napoca constanzeae sp.n. Figs 1-3, 9-13, 17-23, Map.}

TYPE. Holotype $0^{7}$ (ZMB, Arach 48787) from Spain, Andalusia, Benalmádena $\left(36^{\circ} 35^{\prime} 18.2^{\prime \prime} \mathrm{N}, 4^{\circ} 32^{\prime} 15.7^{\prime \prime} \mathrm{W}\right), 65 \mathrm{~m}$ a.s.l., very dry and stony hill (Figs 22, 23), 19.04.2017, M. Schäfer.

ETYMOLOGY. The species is dedicated to Mrs Constanze Schäfer, the wife of the second author, who has been supporting him in his spider studies for many years.

DIAGNOSIS. The male of $N$. constanzeae differs from that of the closely related $N$. insignis (cf. Figs 17 , 18 and 14, 15) in having the visibly shorter embolus, the smaller tegulum of slightly different proportions, and particularly in the lower position of the tegular knob (higher in $N$. constanzeae; as seen in retrolateral view, cf. Figs 14 and 17). The female of $N$. constanze$a e$ is yet unknown.

DISTRIBUTION. The type locality only (Map).

DESCRIPTION. Male (the holotype). Carapace 1.45 long, 1.50 wide, 0.88 high at PLE. Ocular area 1.03 long, 1.05 wide anteriorly and 1.50 wide posteriorly; PMEs are closer to ALEs than to PLEs (Fig. 19).
Diameter of AME 0.33. Abdomen 1.60 long, 1.48 wide. Cheliceral length 0.50. Clypeal height 0.15 . Length of leg segments: I $0.98+0.48+0.60+0.33+0.28$ (2.67); II $0.66+0.43+0.35+0.30+0.28(2.02)$; III $0.75+$ $0.40+0.30+0.36+0.30(2.11) ;$ IV $0.80+0.39+0.38+$ $0.48+0.30$ (2.35). Leg formula: I,IV,III,II. Leg spination: I: Fm d 0-1-2ap; Tb v 0-1-2ap; Mt v 2-2ap. II: Fm d 2ap; Tb v 0-1-0; Mt v 2-2ap. III: Fm d 1ap; Tb pr 0-1, v 2ap; Mt pr and rt 2ap, v 1ap. IV: Fm d 2ap. Coloration (in alcohol) (Figs 9-13). Carapace dark russet, its surface shagreen and iridescent, with black around eyes. Eye field is sparely covered with white recumbent scales. Clypeus brownish red, cheeks orange-red. Chelicerae yellow-orange. Sternum dark brown. Endites and labium light brown. Abdomen flat, strongly overhanging the carapace; thorax is completely covered with anterior third of abdomen, creating a beetle-like appearance (Figs 1-3, 9-12). Dorsum is entirely covered with brown shining scutum and with sparse white recumbent scales (Figs 1, 9). Venter dark grey. Book-lung covers yellow, slightly tinged with brow. Spinnerets short and compact, dark grey. Leg I larger and stronger than others, with swollen femora; Fm, Mt and the basal half of $\mathrm{Tr}$ dark brown, Pt and Tb russet, $\mathrm{Tb}$ tips yellow; $\mathrm{Tb}$ ventrally with a dense fringe of long, thick dark brown bristles (Fig. 13). Legs II-IV: Fm dark brown, remaining segments yellowish brown. Palps dark brown. Palpal structure as in Figs 17, 18; cymbium simple, without ridges or processes; RTA straight, directed anteriad, with a wide base; tegulum oval, with a well-developed TK of which tip is situated at the level of RTA tip 


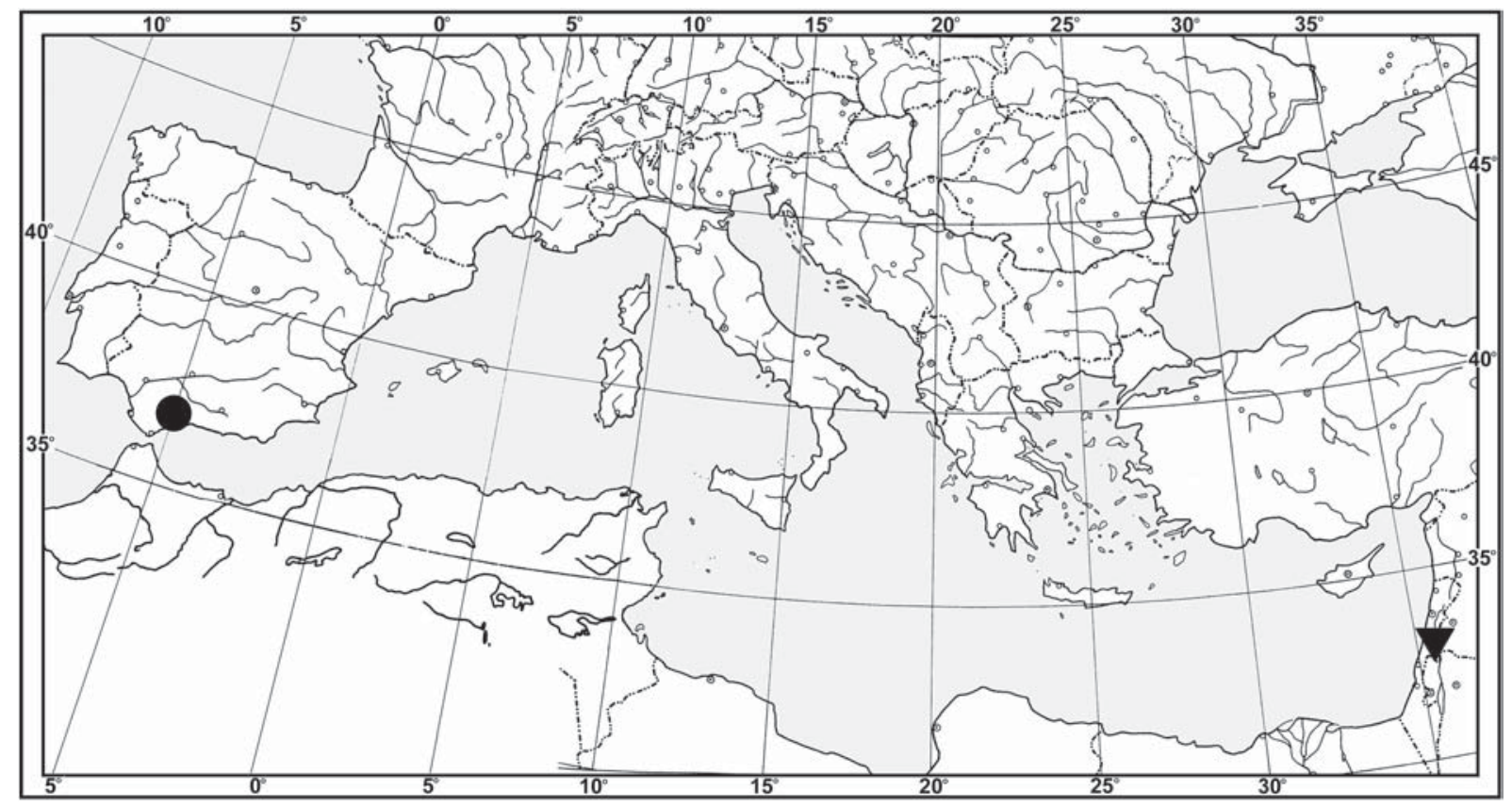

Map. Collecting localities of Napoca insignis (O. Pickard-Cambridge, 1872) (triangle) and N. constanzeae sp.n. (circle). Карта. Точки находок Napoca insignis (O. Pickard-Cambridge, 1872) (треугольник) и N. constanzeae sp.n. (кружок).

(as seen in retrolateral view); embolus very thin, threadlike, poorly visible in ventral view.

Female unknown.

\section{Napoca insignis (O. Pickard-Cambridge, 1872)} Figs 4-8, 14-16, 24-37, Map.

Salticus insignis O. Pickard-Cambridge, 1872: $324\left(\mathrm{DO}^{7}\right)$; the holotype $\sigma^{7}$ in the OUMNH, UK; examined, see Logunov [2001].

For a complete set of taxonomic references see WSC [2017].

MATERIAL EXAMINED. Israel: $10^{\top}, 1$ ( 1 (TAU), 1 ( $\mathrm{NH})$, Golan Hts, c. $1 \mathrm{~km} \mathrm{~N}$ of Merom Golan $\left(33^{\circ} 08^{\prime} 30.0^{\prime \prime} \mathrm{N}\right.$, $35^{\circ} 46^{\prime} 18.0^{\prime \prime}$ E), c. $950 \mathrm{~m}$ a.s.1., 14.05.2012, S.L. Zonstein.

DIAGNOSIS. The male of $N$. insignis differs from that of the closely related $N$. constanzeae sp.n. (cf. Figs 14,15 and 17,18 ) in having the visibly longer embolus, the larger tegulum of slightly different proportions, and particularly in the higher position of the tegular knob (lower in $N$. insignis; as seen in retrolateral view, cf. Figs 14 and 17).

DISTRIBUTION. Two localities in Israel [Logunov, 2001; present data] (Map). However, the type locality was originally recorded as 'Palestine', based on the original data label examined by Logunov [2001], whereas Simon [1901] mentioned it as Syria.

DESCRIPTION. Male. Carapace 2.00 long, 1.90 wide, 1.08 high at PLE. Ocular area 1.40 long, 1.25 wide anteriorly and 2.00 wide posteriorly; PMEs are closer to ALEs than to PLEs (Fig. 4). Diameter of AME 0.40. Abdomen 2.35 long, 2.00 wide. Cheliceral length 0.75 . Clypeal height 0.20 . Length of leg segments: I $1.45+0.88+1.10+0.60+0.38(4.41)$; II $0.90+0.63+0.51+0.43+0.33(2.80) ;$ III $1.04+0.54+$
$0.45+0.53+0.38(2.94) ;$ IV $1.05+0.45+0.53+0.58+$ 0.40 (3.01). Leg formula: I,IV,III,II. Leg spination: I: Fm d 0-1-2ap; Tb v 0-1-2ap; Mt v 2-2ap. II: Fm d 2ap; Tb v 0-1, v 1-1; Mt v 2-2ap. III: Fm d 2ap; Tb pr 0-1, v 1ap; Mt pr and rt 2ap, v 1ap. IV: Fm d 1ap; Tb pr 0-1, v 1-1ap; Mt rt 1ap. Coloration (in alcohol) (Figs 4-8). Carapace orange-red, its surface shagreen and iridescent, with black around eyes. Clypeus, cheeks and chelicerae orange-red. Sternum brown. Endites and labium orange-red. Abdomen overhangs the thorax (Fig. 7). Dorsum dark grey, entirely covered with brown shining scutum and with two pairs of large round yellow spots (Fig. 4). Sides and venter dark grey. Booklung covers yellow, slightly tinged with brown. Spinnerets small and compact, brown-grey. Leg I larger than others, with swollen femora; Fm, Mt and the basal half of Tr dark brown; Pt and Tb orange; the distal half of Tr yellow; Tb ventrally with a dense fringe of long and thick dark brown bristles. Legs II-IV: all Fm dark brown, remaining segments yellowish brown. Palps light brown. Palpal structure as in Figs 14, 15; cymbium simple, without ridges or processes; RTA straight, directed anteriad, with a wide base; tegulum oval, with a well-developed TK of which tip is situated lower than the RTA tip (as seen in retrolateral view); embolus thread-like.

Female (specimen from the TAU): Carapace 1.95 long, 2.05 wide, 1.10 high at PLE. Ocular area 1.43 long, 1.35 wide anteriorly and 2.13 wide posteriorly; PMEs are closer to ALEs than to PLEs (Fig. 34). Diameter of AME 0.43. Abdomen 3.05 long, 2.40 wide. Cheliceral length 0.65. Clypeal height 0.19. Length of leg segments: I $1.13+0.65+0.70+0.50+0.36(3.34)$; 


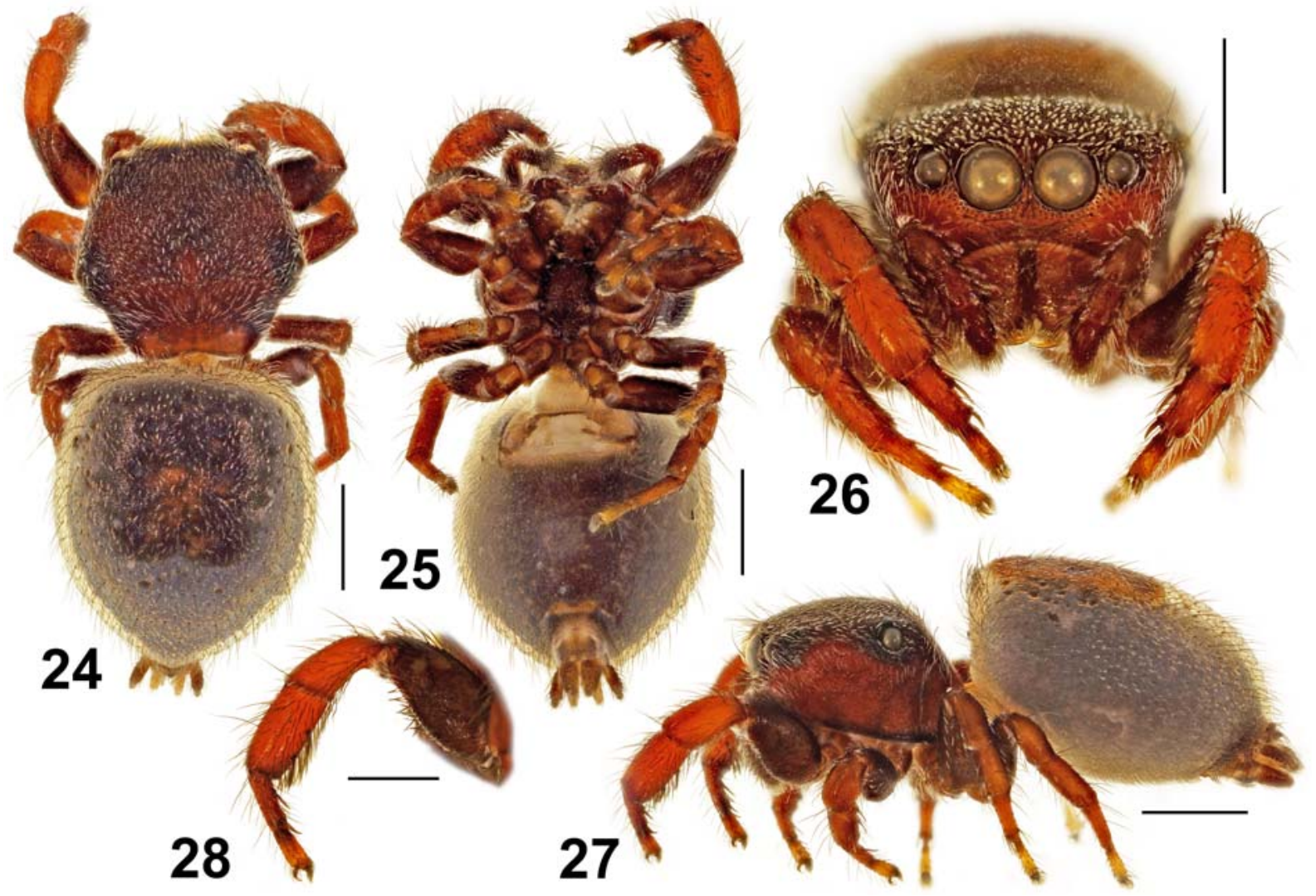

Figs 24-28. General appearance and the first legs of the female of Napoca insignis (O. Pickard-Cambridge, 1872), the specimen from the TAU: 24 - dorsal view; 25 - ventral view; 26 - frontal view, 27 - lateral view, 28 - left first legs, retrolateral view. Scale bars = $1 \mathrm{~mm}$.

Рис. 24-28. Общий вид и передняя нога самки Napoca insignis (O. Pickard-Cambridge, 1872), экземпляр из ТAU: 24 — вид сверху; 25 - вид снизу; 26 - вид спереди, 27 - вид сбоку, 28 - передняя нога, вид сзади-сбоку. Масштаб 1 мм.

II $0.93+0.60+0.50+0.45+0.35(2.83) ;$ III $1.03+$ $0.50+0.48+0.48+0.45(2.94) ;$ IV $1.10+0.55+0.58$ $+0.63+0.40$ (3.26). Leg formula: I,IV,III,II. Leg spination: I: I: Fm d 0-1-2ap; Tb pr 0-1, v 1-1; Mt v 22ap. II: Fm d 2ap; Tb pr 0-1, v 1-1; Mt v 2-2ap. III: Fm d 1ap; Tb pr 0-1, v 1ap; Mt pr and rt 2ap, v lap. IV: Fm d 1 ap; Tb v 1ap. Coloration (in alcohol) (Figs 24-28). Carapace russet, its surface shagreen and iridescent, sparsely covered with white recumbent scales, with black around eyes. Clypeus, cheeks and chelicerae orange-red. Sternum dark brown. Endites and labium light brown. Abdomen entirely dark grey, without colour pattern, the proximal half of dorsum is covered with brown shining scutum. Book-lung covers yellow, slightly tinged with brownish. Spinnerets dark grey. Legs: Fm dark brown, remaining segments brownish yellow. Palps yellowish brown. Epigyne and spermathecae as in Figs 29-33; epigyne with a well-developed central atrium surrounded on both sides by the atrial lips; central blind-ending pocket well-developed; spermathecae two-chambered, as in all other representative of the Harmochireae; the first loop of the insemination ducts present; fertilisation ducts well-developed and visible.
ACKNOWLEDGEMENTS. We wish to express our warmest thanks to Sergei L. Zonstein (of the TAU) for giving access to the newly collected salticid material from Israel.

\section{References}

Logunov D.V. 1996. Taxonomic remarks on the genera Neaetha Simon, 1884 and Cembalea Wesolowska, 1993 (Araneae: Salticidae) // Genus. Vol.7. No.3. P.515-532.

Logunov D.V. 2000. A new endemic genus and three new species of the jumping spiders (Araneae: Salticidae) from the Seychelles Islands // Cimbebasia. Vol.16. P.261-267.

Logunov D.V. 2001. A redefinition of the genera Bianor Peckham \& Peckham, 1885 and Harmochirus Simon, 1885, with the establishment of a new genus Sibianor gen. n. (Araneae: Salticidae) // Arthropoda Selecta. Vol.9 (for 2000). No.4. P.221286.

Logunov D.V. 2009. Further notes on the Harmochireae of Africa (Araneae, Salticidae, Pelleninae) // Stoev P., Dunlop J., Lazarov S. (eds.). A life caught in a spider's web. Papers in arachnology in honour of Christo Deltshev. ZooKeys. Vol.16. P.265-290.

Maddison W.P. 2015. A phylogenetic classification of jumping spiders (Araneae: Salticidae) // Journal of Arachnology. Vol.43. No.3. P.231-292. doi:10.1636/arac-43-03-231-292 

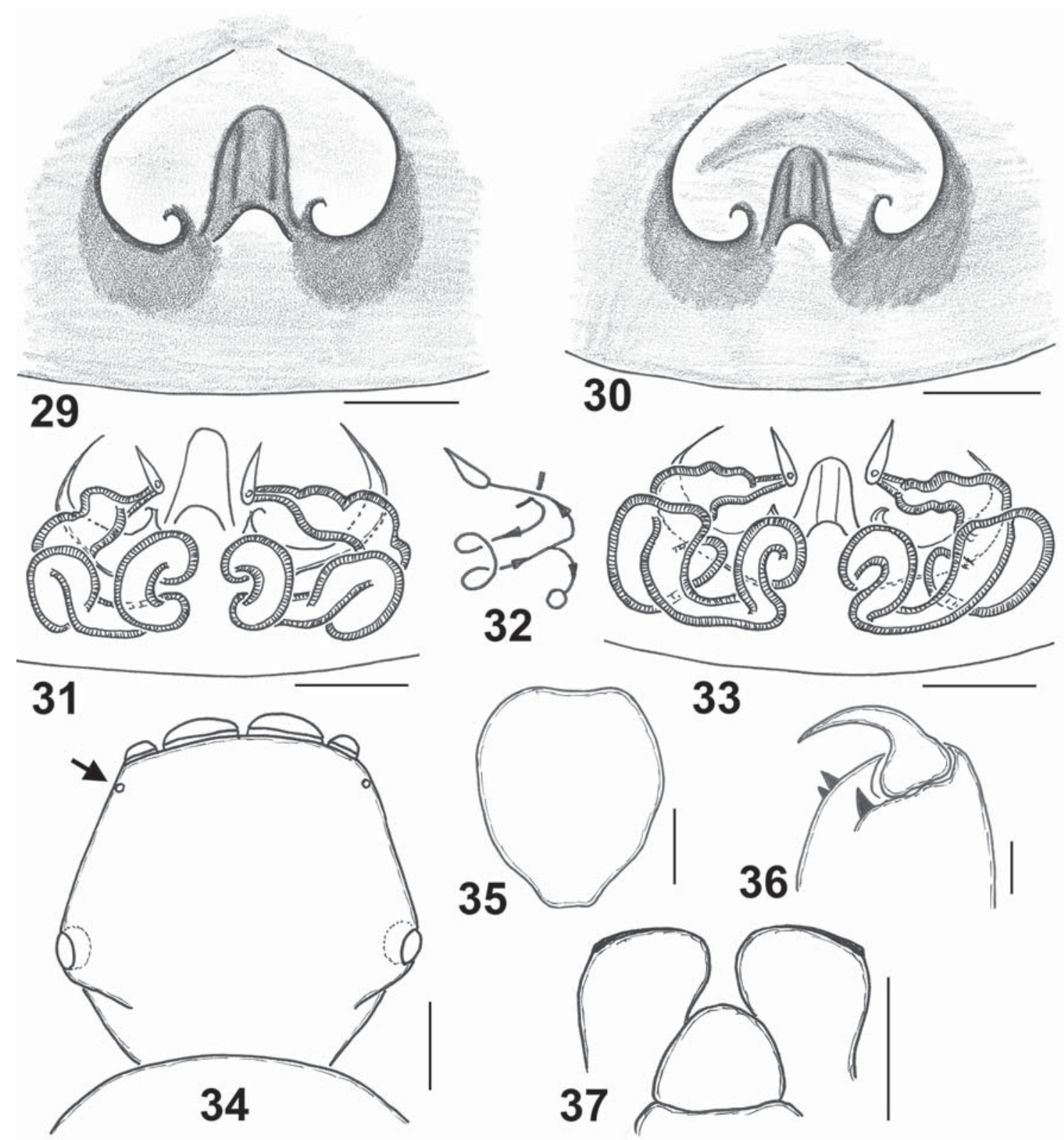

Figs 29-37. Copulatory organs and somatic characters of the female of Napoca insignis (O. Pickard-Cambridge, 1872), the specimen from the TAU: 29, 30 - epigyne, ventral view; 31, 33 - spermathecae, dorsal view; 32 - diagrammatic course of the insemination ducts; 34 - carapace, dorsal view; 35 - sternum, ventral view; 36 - left chelicerae, ventral view; 37 - endites and labium, ventral view. Scale bars $=(29-33,36) 0.1 \mathrm{~mm},(35) 0.25 \mathrm{~mm},(34,37) 0.5 \mathrm{~mm}$.

Рис. 29-37. Копулятивные органы и соматические признаки самки Napoca insignis (O. Pickard-Cambridge, 1872), экземпляр из TAU: 29, 30 - эпигина, вид снизу; 31, 33 - сперматека, вид сверху; 32 - схематическое изображение канальцев семепроводов; 34 - головогрудь, вид сверху; 35 - стернум, вид снизу; 36 - левая хелицера, вид снизу; 37 - эндиты и нижняя губа, вид снизу. Масштаб $(29-33,36)$ 0,1 мм, (35) 0,25 мм, $(34,37)$ 0,5 мм.

Maddison W.P., Bodner M.R., Needham K.M. 2008. Salticid spider phylogeny revisited, with the discovery of a large Australasian clade (Araneae: Salticidae) // Zootaxa. Vol.1893. P.4964.

Ono H. 1988. A revisional study of the spider family Thomisidae (Arachnida, Araneae) of Japan. Tokyo: National Science Museum. 252 pp.

Prószyński J. 1990. Catalogue of Salticidae (Araneae): Synthesis of Quotations in the World Literature since 1940, with Basic
Taxonomic Data since 1758. Wyższa Szkola Rolniczo-Pedagogiczna W Siedlcach. 366 pp.

Simon E. 1901. Histoire naturelle des araignées. Paris. T.2. P.381668.

WSC 2017. World Spider Catalog. Natural History Museum Bern, online at: http://wsc.nmbe.ch, version 18.0 (accessed on July 25th, 2017).

Responsible editor K.G. Mikhailov 